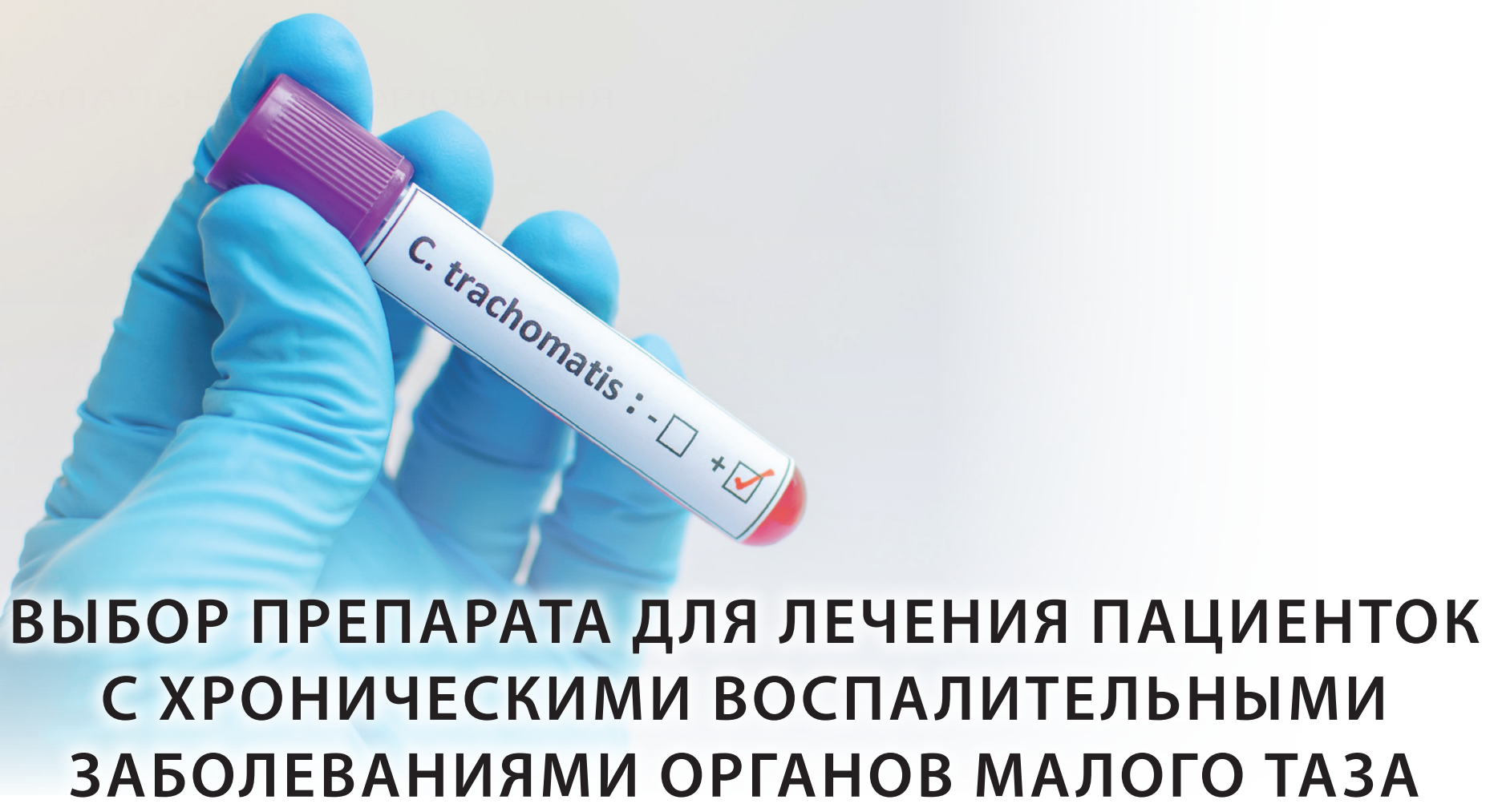

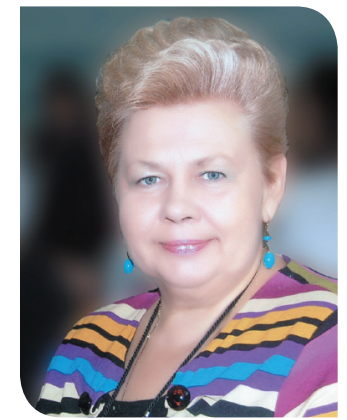

О.В. ГРИЩЕНКО

д. мед. н., профессор, заведующая кафедрой перинатологии, акушерства и гинекологии Харьковской медицинской академии последипломного образования

\section{И.В. ЛАХНО}

к. мед. н., доцент кафедры перинатологии, акушерства и гинекологии ХМАПО

\section{В.И. ОСТАНИНА}

Харьковский городской

клинический родильный дом С неонатологическим стационаром

Е.В. МИлютИН

Харьковский городской

клинический родильный дом с

неонатологическим стационаром

Контакты:

Грищенко Ольга Валентиновна ХМАПО, кафедра перинатологии, акушерства и гинекологии

61176, Харьков, Корчагинцев, 58

тел.: + 38 (057) 71135 56;

+38 (057) 7118025

e-mail: office@med.edu.ua

\section{ВВЕДЕНИЕ}

Пациентки с хроническими воспалительными заболеваниями органов малого таза (В3ОМТ) составляют значительную долю всего контингента женщин, обращающихся за помощью к акушеру-гинекологу (зачастую свыше 2/3). В амбулаторной практике отмечается тенденция к отождествлению понятий тазовой боли и ВЗОМТ. Выявление этиологического фактора в настоящий момент не представляет сложной задачи. Этому способствует внедрение высокоинформативных методов обследования на возбудители заболеваний, передающихся половым путем: Chlamydia trachomatis, Neisseria gonorrhoeae, Mycoplasma hominis и пр., что побуждает врачей к проведению неоднократных дорогостоящих курсов антибактериальной терапии [2, 8]. Выявленный возбудитель становится мишенью для медикаментозной атаки. При отсутствии клинического эффекта, как правило, происходит замена антибактериальных препаратов. В результате в очаге воспаления преобладает сапрофитная флора, отмечается дисбиоз кишечника, у пациентки формируется полихимиорезистентность, иммунодефицит [4]. Поэтому успех определяет правильный менеджмент пациенток с учетом комплаентности выбранного препарата для антибактериальной терапии.

\section{АНАЛИЗ ЛИТЕРАТУРНЫХ ДАННЫХ И ПОСТАНОВКА ЗАДАЧИ ИССЛЕДОВАНИЯ}

В гинекологическом стационаре достаточно редко встречаются пациентки с первым эпизодом В3ОМТ, когда проведение качественной санации позволяет завершить воспалительную реакцию тканей, предотвратить развитие осложнений. Частота хронизации ВЗОМТ составляет около $60 \%$. Каждая пятая из этой категории женщин в будущем является кандидатом для оперативного лечения по поводу гнойных тубоовариальных опухолей [5, 7]. Поэтому инфекционный фактор приобретает особое значение, определяя политопность локализации и выраженность деструктивных процессов в тканях. Эволюция в мире микроорганизмов и простейших привела к появлению их кооперативного синергизма в генезе В3ОМТ, чему способствовали десятилетия применения антибиотиков и особенно внедрение синдромного подхода в терапии.

Для определения приоритетов лечебной стратегии необходимы четкие представления о наиболее частых возбудителях В3ОМТ и методах их лечения. В практике наиболее часто встречается хламидийная и микоплазменная инфекция, частота гонореи постепенно уменьшается. Для этих возбудителей патогенетически характерно хроническое пролиферативное воспаление с формированием перитубарных адгезий [8].

Среди антибактериальных препаратов с широким спектром действия наибольшей популярностью в лечении неосложненных форм В3ОМТ пользуются тетрациклины, фторхинолоны и макролиды, при этом последние признаны оптимальными $[1,3,6]$. Их концентрация в тканях в 10-100 раз превышает плазмовую, что обеспечивает санирующий эффект в отношении внутриклеточных возбудителей. В этой группе наилучшей биодоступностью, высокой эффективностью и возможностью проведения пульс-терапии, что определяет высокий комплаенс, обладает азитромицин. Он способен 
накапливаться в среде с низкой $\mathrm{pH}$, что характерно для очага воспаления, а также демонстрирует постантибиотический эффект, продолжающийся до 7 суток, и стимулирует фагоцитоз [2].

На украинском фармацевтическом рынке представлены более 20 препаратов азитромицина. Цена на брендовый препарат значительно превышает стоимость генериков, которые не всегда тестированы в достаточном объеме. При этом выбор препарата должен основываться на принципах доказательности, высокой комплаентности и фармакоэкономической доступности. Единственным генерическим препаратом азитромицина в Украине с установленной биоэквивалентностью является хемомицин (производство компании Hemofarm, группа компаний Stada). Он демонстрирует одинаковую с брендовым азитромицином эффективность в лечении ВЗОМТ хламидийной, микоплазмовой и уреаплазмовой этиологии. Это обосновывает наилучшие среди всех представителей азитромицина фармакоэкономические характеристики [2-4].

Целью работы было изучение сравнительной эффективности препарата хемомицин и других генериков азитромицина в лечении пациенток с хроническими В3ОМТ хламидийной этиологии.

\section{МАТЕРИАЛЫ И МЕТОДЫ ИССЛЕДОВАНИЯ}

В исследовании приняли участие 124 пациентки с хроническими В3ОМТ хламидийной этиологии, которые были поделены на несколько клинических групп. В I группе (основной) под наблюдением находились 68 женщин, у 36 из которых был неосложненный хламидийный эндоцервицит (подгруппа IA) и у 32 - хронический сальпингоофорит (XCO) В стадии обострения (подгруппа ІБ). Во II группе (сравнения) находилось 56 пациенток. Среди них у 30 был диагностирован неосложненный хламидийный эндоцервицит (подгруппа IIA) и у 26 - двусторонний ХСО в стадии обострения (подгруппа ІІБ).

Пациенткам основной группы при эндоцервиците назначали хемомицин по 0,5 г 2 раза в сутки на 1, 7 и 14 день лечения, лавомакс по 125 мг (1 таблетка) один раз в день в первые 2 дня лечения, а затем по 125 мг через день (всего 10 таблеток на курс лечения), а также свечи гексикон интравагинально 2 раза в сутки. В подгруппе IБ женщинам с XСО дополнительно назначали цефтриаксон по 1 г внутримышечно 2 раза в сутки, метрогил 500 мг внутривенно капельно 2 раза в сутки, ректальные свечи с диклофенаком или кетопрофеном по 1 свече 2 раза в сутки в течение недели. В группе сравнения у пациенток с эндоцервицитом применяли генерические препараты азитромицина различных производителей также в режиме пульс-терапии, циклоферон по 2 мл внутримышечно через день и многокомпонентные свечи с антимикробным, противогрибковым и противовоспалительным компонентом вагинально на ночь в течение 10 дней. Дополнительный комплекс лечения в подгруппе ІІА был аналогичен комплексу для пациенткок с XСО подгруппы IA.

Всем пациенткам проводили бактериоскопическое и бактериологическое исследование микрофлоры влага- лища, кольпоскопию, онкоцитологическое исследование, обследование на возбудители заболеваний, передающихся половым путем, методами иммуноферментного анализа и полимеразной цепной реакции до и через 1 месяц от начала лечения.

Оценивали динамику клинической симптоматики в виде тазовой боли, патологических изменений придатков при бимануальном исследовании, чувства зуда, жжения во влагалище и патологических белей (по 3-бальной шкале: слабо выражены - 1 балл, умеренно 2 балла, выраженные - 3 балла) до курса терапии и по его завершении.

У обследованных женщин определяли содержание иммуноглобулинов IgG и IgA в цервикальной слизи методом простой радиальной иммунодиффузии по Манчини с использованием антисывороток с помощью аппарата «Реагент». Уровень иммуноглобулинов оценивали до и через 1 месяц после начала лечения.

Для контроля использовали показатели 30 практически здоровых пациенток, проходивших профилактическое обследование.

Результаты работы были обработаны с использованием методов параметрической и непараметрической статистики с помощью пакета программ Excel.

\section{РЕЗУЛЬТАТЫ ИССЛЕДОВАНИЯ И ИХ ОБСУЖДЕНИЕ}

В ходе проведения инфектологического обследования у большинства пациенток выявлено микст-инфицирование (95,6\% и 96,4\% в I и II группах соответственно). Из патогенных и условно-патогенных микроорганизмов в основной группе и группе сравнения встречались соответственно: Staphylococcus epidermidis - 44,17\% и 44,6\%; Gardnerella vaginalis - 38,2\% и 37,5\%; Escherichia coli - 27,9\% и 30,3\%; Enterococcus faecalis - 16,2\% и 17,9\%; Bacteroides - 11,8\% и 10,7\%; другие - 7,4\% и 7,1\%. В анализе влагалищных выделений у всех обследованных пациенток обнаружено высокое лейкоцитарное число, кокковая флора. Кольпоскопическая картина характеризовалась наличием признаков цервицита, в некоторых случаях образованием «полей» (рис. 1).

Выраженность клинической симптоматики была максимальной у пациенток с XСО в подгруппах IA и IБ (табл. 1).

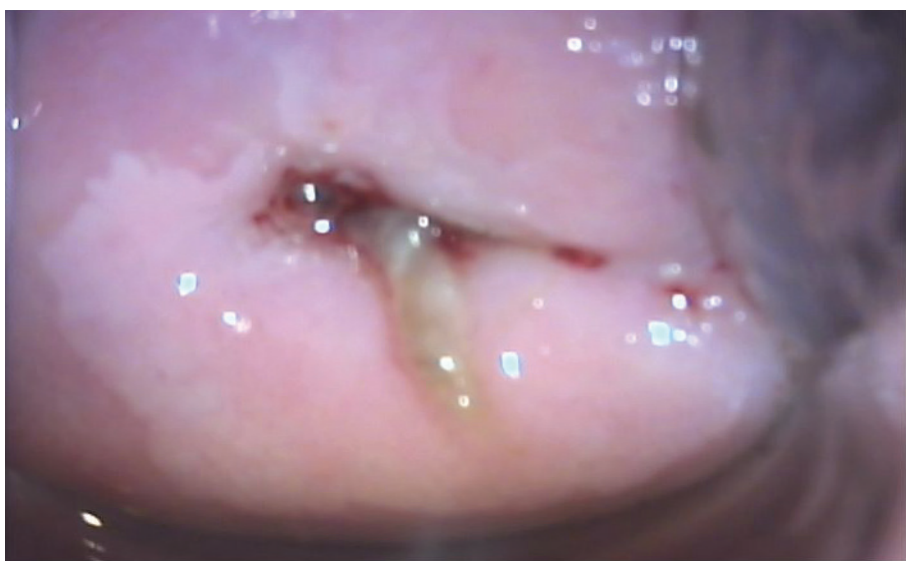

РИСУНОК 1. КОЛЬПОСКОПИЧЕСКАЯ КАРТИНА УПАЦИЕНТКИ N ОСНОВНОЙ гРУппЫ 
ТАБЛИЦА 1. ОЦЕНКА КЛИНИЧЕСКОЙ СИМПТОМАТИКИ ОБСЛЕДОВАННЫХ ПАЦИЕНТОК (БАЛЛЫ)

\begin{tabular}{|c|c|c|c|c|}
\hline Симптом & Подгруппа IA & Подгруппа ІБ & Подгруппа ІІА & Подгруппа ІІБ \\
\hline Тазовая боль & $0,1 \pm 0,1$ & $2,6 \pm 0,1^{*}$ & $0,1 \pm 0,1$ \\
\hline $\begin{array}{c}\text { Изменения придатков при } \\
\text { бимануальном исследовании }\end{array}$ & $0,1 \pm 0,1$ & $2,8 \pm 0,2^{*}$ & $0,1 \pm 0,1$ \\
\hline $\begin{array}{c}\text { Слизисто-гнойные бели } \\
\text { Ощущение зуда, жжения во }\end{array}$ & $2,6 \pm 0,1^{*}$ & $2,8 \pm 0,1^{*}$ & $2,7 \pm 0,1^{*}$ \\
\hline \begin{tabular}{c} 
влагалище \\
\hline
\end{tabular} & $2,9 \pm 0,1^{*}$ & $2,8 \pm 0,2^{*}$ & $2,8 \pm 0,1^{*}$ \\
\hline
\end{tabular}

* различия статистически значимы по сравнению с контролем, $\mathrm{p}<0,05$

ТАБЛИЦА 2. РЕГРЕССИЯ ПОКАЗАТЕЛЕЙ БАЛЛЬНОЙ ОЦЕНКИ ВЫРАЖЕННОСТИ КЛИНИЧЕСКИХ СИМПТОМОВ ПОД ВЛИЯНИЕМ ЛЕЧЕНИЯ (В СООТВЕТСТВИИ C W-КРИТЕРИЕМ УИЛКОКСОНА-МАННА-УИТНИ)

\begin{tabular}{|c|c|c|c|c|c|c|c|c|}
\hline \multirow{3}{*}{ Симптом } & \multicolumn{8}{|c|}{ Показатели регрессии } \\
\hline & \multicolumn{2}{|c|}{ Подгруппа IA } & \multicolumn{2}{|c|}{ Подгруппа ІБ } & \multicolumn{2}{|c|}{ Подгруппа IIA } & \multicolumn{2}{|c|}{ Подгруппа ІІБ } \\
\hline & w & $\mathbf{p}$ & w & p & w & p & w & p \\
\hline $\begin{array}{c}\text { Изменения придатков при } \\
\text { бимануальном исследовании }\end{array}$ & $-0,1$ & $<0,1$ & $-2,5$ & $<0,05$ & $-1,0$ & $<0,1$ & $-1,6$ & $<0,05$ \\
\hline
\end{tabular}

у этого контингента больных отмечался выраженный болевой синдром, значительные изменения структуры придатков при бимануальном исследовании в виде пастозности, тяжистости и увеличения размеров. При этом показатели балльной оценки патологических белей и ощущения зуда, жжения во влагалище были практически одинаковыми у пациенток всех подгрупп. Выявленная клиническая картина была связана с характерными для хламидийной инфекции патогенетическими особенностями, обусловленными тропностью к цилиндрическому эпителию, способностью стимулировать пролиферацию соединительной ткани, а также нарушениями микроциркуляции в очаге воспаления. Эти изменения могли быть вызваны оксидативным стрессом и эндотелиальной дисфункцией, ассоциированными с наличием хламидийной инфекции $[1,5,8]$.

Под влиянием проведенного лечения отмечалась практически полная редукция клинической симптоматики у контингента основной группы (табл. 2). В группе сравнения позитивная динамика была значительно менее выраженной. По-видимому, ключевую роль в обеспечении максимального лечебного эффекта в I клинической группе играла высокая биодоступность, длительный постантибиотический и возможный иммунотропный эффект препарата хемомицин. Эти качества хемомицина позволяют считать его полностью соответствующим режиму пульс-терапии. Исчезновение болевого синдрома, улучшение анатомической структуры придатков матки, ликвидация слизисто-гнойных белей и вагинального дискомфорта демонстрировали полное завершение воспалительной реакции тканей без наличия латентного патологического следа у пациенток основной группы.
В основной группе эффективность лечения хламидийной инфекции по данным контрольного обследования составила 100\%, а в группе сравнения в 16,1\% случаев отмечены неудачи. Восстановление нормального вагинального биотопа было зарегистрировано в 95,6\% наблюдений в I группе. Во II группе у 23,2\% пациенток сохранялась кокковая флора. Появление лактобациллярного пейзажа влагалища сопровождалось формированием условий для нормальной регенерации эпителия шейки матки (рис. 2).

В ходе изучения концентрации иммуноглобулинов в цервикальной слизи обследованных пациенток было установлено, что содержание $\lg$ А, секреторного $\lg$ А и $\lg G$ было значительно снижено (табл. 3). Это демонстрировало нарушение процессов иммунной защиты на фоне поражения хламидиями эпителиоцитов эндоцервикса. После лечения нормализация уровня иммуноглобулинов отмечалась только у контингента основной группы, что было об-

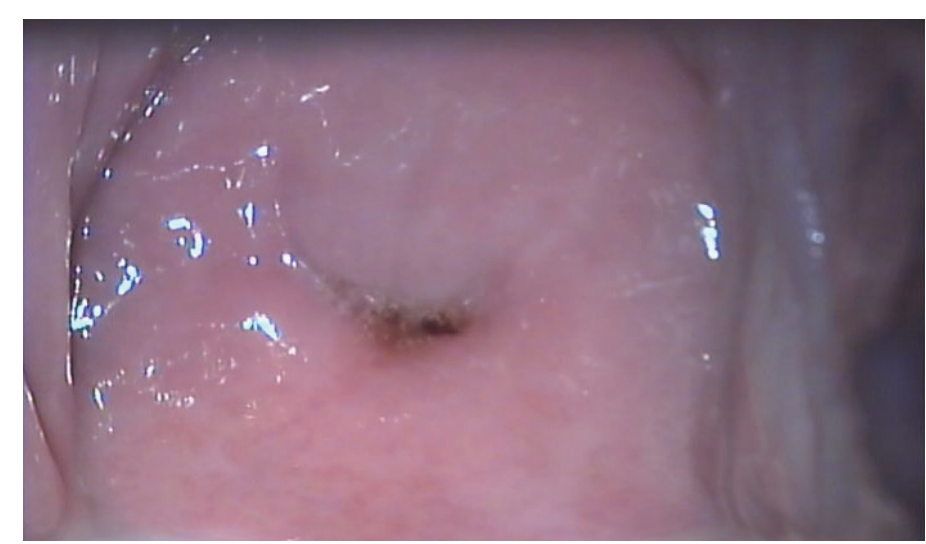

РИСУНОК 2. КОЛЬПОСКОПИЧЕСКАЯ КАРТИНА У ПАЦИЕНТКИ N ОСНОВНОЙ ГРУППЫ ПОСЛЕ ЛЕЧЕНИЯ 
ТАБЛИЦА З. УРОВЕНЬ ИММУНОГЛОБУЛИНОВ В ЦЕРВИКАЛЬНОЙ СЛИЗИ ОБСЛЕДОВАННЫХ ПАЦИЕНТОК (Г/Л)

\begin{tabular}{|c|c|c|c|}
\hline Тип иммуноглобулина & Подгруппа & \multicolumn{2}{|c|}{ Концентрация } \\
\hline $\lg A$ & $\begin{array}{l}\text { IA } \\
\text { I } \\
\text { II } \\
\text { II } \\
5\end{array}$ & $\begin{array}{l}0,05 \pm 0,01^{*} \\
0,06 \pm 0,01^{*} \\
0,05 \pm 0,01^{*} \\
0,05 \pm 0,01^{*}\end{array}$ & $\begin{array}{c}0,16 \pm 0,01 \\
0,15 \pm 0,01 \\
0,07 \pm 0,01^{*} \\
0,08 \pm 0,01^{*}\end{array}$ \\
\hline $\lg G$ & $\begin{array}{l}\text { IA } \\
\text { ID } \\
\| A \\
\| \text { II }\end{array}$ & $\begin{array}{l}0,42 \pm 0,05^{*} \\
0,44 \pm 0,04^{*} \\
0,41 \pm 0,04^{*} \\
0,42 \pm 0,04^{*}\end{array}$ & $\begin{array}{c}0,88 \pm 0,05 \\
0,86 \pm 0,05 \\
0,62 \pm 0,05^{*} \\
0,64 \pm 0,05^{*}\end{array}$ \\
\hline
\end{tabular}

* различия статистически значимы по сравнению с контролем, $\mathrm{p}<0,05$

условлено полной элиминацией хламидийной инфекции, завершением воспалительной реакции и восстановлением структурно-функциональных свойств шеечного эпителия.

Проведенная работа позволяет считать, что назначение препарата хемомицин обеспечивает высокий комплаенс в лечении пациенток с эндоцервицитом и ХСО хламидийной этиологии. По своим фармакоэкономическим качествам и клинической эффективности хемомицин является препаратом выбора антибактериальной терапии генитального хламидиоза.

\footnotetext{
'Locus minoris resistentiae (лат. - место наименьшего сопротивления) — орган, ткань или система организма, прежде всего подвергающаяся повреждению при различных заболеваниях (прим. ред.).
}

\section{ЛИТЕРATУPA/REFERENCES}

\section{1. Белоцерковцева, Д.Д.}

Применение азитромицина (Сумамеда) для лечения хламидийной инфекции в гинекологической практике / Д.Д. Белоцерковцева, П.В. Буданов // Вопросы гинекологии акушерства и перинатологии, - 2003. - Т. 2, № 3. - С. 81-84.

Belotserkovtseva, D.D., Budanov, P.V.

"Azithromycin (Sumamed) for the treatment of chlamydial infection in gynecological practice." Questions of Gynecology, Obstetrics and Perinatology 2.3 (2003): 81-4.

\section{2. Зіменківський, А.Б.}

Принципи раціонального вибору протимікробних лікарських засобів для фармакотерапії захворювань, спричинених збудниками атипової інфекції в реальній клінічній практиці / А.Б. Зіменківський, Т.Б. Ривак // Клінічна фармація, фармакотерапія та медична стандартизація. - 2009. - № 3-4. - С. 131-137.

Zimenkivskyi, A.B., Ryvak, T.B.

"Principles of rational choice of antimicrobial drugs for pharmacotherapy of diseases caused by atypical pathogens infection in clinical practice." Clinical Pharmacy, Pharmacotherapy and Medical Standardization 3-4 (2009): 131-7.

3. Карпов, 0.И.

Оригинальные препараты и копии макролидов: тенденции противостояния / 0.И. Карпов // Фарматека. - 2004. - № 82. - С. 3-4.

Karpov, 0.I.

"Original drugs and copies of macrolides: opposition trends." Pharmateka 82 (2004): 3-4.

4. Митрохин, В.Е.

Оригинальные препараты и дженерики. Проблемы выбора / В.Е. Митрохин // Материалы 1-го Сибирского конгресса акушеров-гинекологов и дерматовенерологов. «Актуальные вопросы акушерства, гинекологии и дерматовенерологии». - Новосибирск: 2006. C. $41-43$.

Mitrokhin, B.E.

"Original drugs and generics. Selection problems." // 1st Siberian Congress of ObstetriciansGynecologists and Dermatologists Materials. Actual problems of obstetrics, gynecology and dermatology. Novosibirsk (2006): 41-43.

\section{ВЫВОДЫ}

1. Использование препарата хемомицин превосходит по своей эффективности прочие генерики азитромицина при проведении пульс-терапии пациенткам с хламидийным цервицитом и ХCO.

2. Назначение хемомицина обеспечивает полную элиминацию хламидийной инфекции, завершение воспалительной реакции тканей без locus minoris resistentiae', восстановление лактобациллярного биотопа и защитных свойств цервикальной слизи.

3. Хемомицин является наиболее комплаентным генерическим препаратом азитромицина в Украине, а с учетом более низкой цены имеет преимущество перед брендовым лекарственным средством.

\section{Haggerty, C.L., Ness, R.B.}

"Diagnosis and treatment of pelvic inflammatory disease." Womens Health 4.4 (2008): 383-397.

6. Rowland, K., Ewigman, B.

"Azithromycin for PID beats doxycycline on all counts."The journal of family practice 56.12 (2007): 1006-8.

7. Savaris, R.F., Teixeira, L.M., Torres, T.G., et al.

"Comparing ceftriaxone plus azithromycin or doxycycline for pelvic inflammatory disease: a randomized controlled trial." Obstet Gynecol 110.1 (2007): 53-60.

8. Soper, D.E.

"Pelvic inflammatory disease." Obstet Gynecol 116.2.1 (2010): 419-28. i

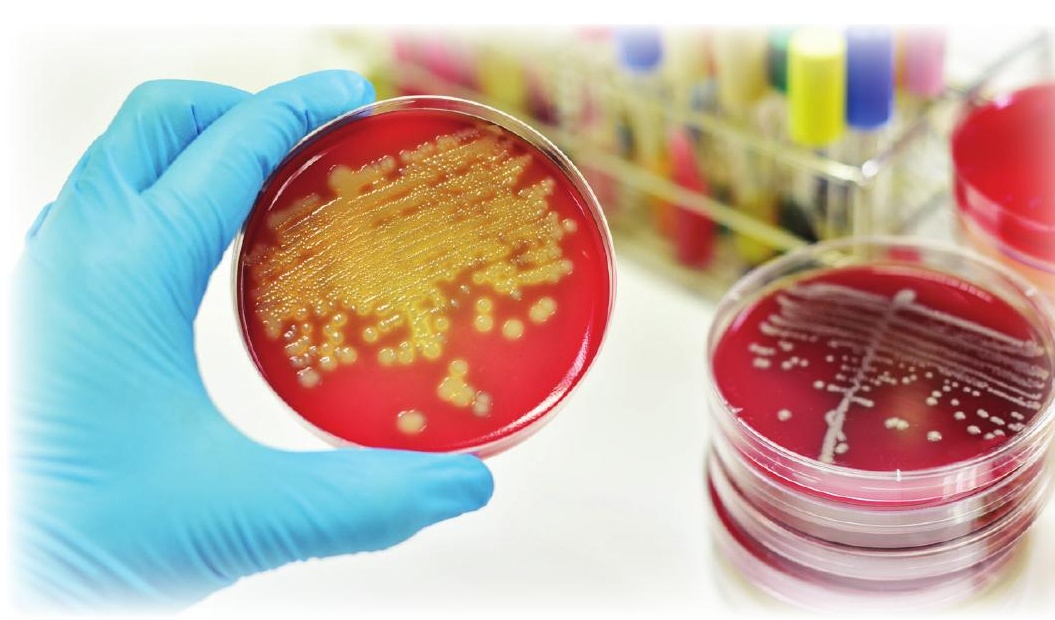




\section{ВЫБОР ПРЕПАРАТА ДЛЯ ЛЕЧЕНИЯ ПАЦИЕНТОК С ХРОНИЧЕСКИМИ ВОСПАЛИТЕЛЬНЫМИ ЗАБОЛЕВАНИЯМИ ОРГАНОВ МАЛОГО ТАЗА}

О.В. Грищенко, д. мед. н., профессор, зав. кафедрой перинатологии, акушерства и гинекологии ХМАПО

И.В. Лахно, к. мед. н., доцент кафедры перинатологии, акушерства и гинекологии ХМАПО

B.И. Останина, Харьковский городской клинический родильный дом с неонатологическим стационаром

Е.В. Милютин, Харьковский городской клинический родильный дом с неонатологическим стационаром

Пациентки с хроническими воспалительными заболеваниями органов малого таза составляют значительную долю всего контингента женщин, обращающихся за помощью к акушеру-гинекологу (зачастую превышающую две трети). Для определения приоритетов лечебной стратегии необходимы четкие представления о наиболее частых возбудителях воспалительных заболеваний органов малого таза и методах их лечения. В практике наиболее часто встречается хламидийная и микоплазменная инфекция, а частота гонореи постепенно уменьшается. Наиболее популярными антибактериальными препаратами с широким спектром действия, использующимися в лечении неосложненных форм воспалительных заболеваний органов малого таза, признаны макролиды. Среди них наилучшей биодоступностью, высокой эффективностью и возможностью проведения пульс-терапии обладает азитромицин. На украинском фармацевтическом рынке представлены более 20 препаратов азитромицина. Единственным генерическим препаратом азитромицина в Украине сустановленной биоэквивалентностью является хемомицин.

Проведено сравнительное исследование эффективности препарата хемомицин (основная группа) и других генериков азитромицина (группа сравнения), зарегистрированных в Украине, в лечении 124 пациенток с эндоцервицитом и хроническим сальпингоофоритом хламидийной этиологии.

Результаты исследования показали, что под влиянием лечения отмечалась практически полная редукция клинической симптоматики у женщин основной группы. В группе сравнения позитивная динамика была значительно менее выражена. В основной группе эффективность лечения хламидийной инфекции по данным контрольного обследования составила 100\%, а в группе сравнения в 16,1\% случаев отмечены неудачи. Восстановление нормального вагинального биотопа был0 зарегистрировано в 95,6\% наблюдений в основной группе, в группе сравнения у $23,2 \%$ пациенток сохранялась кокковая флора.

Таким образом, использование хемомицина превосходит по своей эффективности прочие генерики азитромицина при проведении пульс-терапии. Назначение хемомицина обеспечивает полную элиминацию хламидийной инфекции, завершение воспалительной реакции тканей, восстановление лактобациллярного биотопа и защитных свойств цервикальной слизи. По своим фармакоэкономическим качествам и клинической эффективности хемомицин является препаратом выбора антибактериальной терапии генитального хламидиоза.

Ключевые слова: воспалительные заболевания органов малого таза, хламидиоз, азитромицин, хемомицин.

\section{ВИБІР ПРЕПАРАТУ ДЛЯ ЛІКУВАННЯ ПАЦІЕНТОК ІЗ ХРОНІЧНИМИ ЗАПАЛЬНИМИ ЗАХВОРЮВАННЯМИ ОРГАНІВ МАЛОГО ТАЗУ}

О.В. Грищенко, д. мед. н., професор, зав. кафедрою перинатології, акушерства і гінекології ХМАПО

І.В. Лахно, К. мед. н., доцент кафедри перинатології, акушерства і гінекології ХМАПО

B.І. Останіна, Харківський міський клінічний пологовий будинок з неонатологічним стаціонаром

Є.В. Мілютін, Харківський міський клінічний пологовий будинок з неонатологічним стаціонаром

Пацієнтки з хронічними запальними захворюваннями органів малого тазу становлять значну частку усього контингенту жінок, які звертаються по допомогу до акушерагінеколога (часто більше двох третин). Для визначення пріоритетів лікувальної стратегії необхідні чіткі уявлення про найчастіші збудники запальних захворювань органів малого тазу і методи їхнього лікування. У практиці найчастіше зустрічається хламідійна і мікоплазмова інфекція, а частота гонореї поступово зменшується. Найбільш популярними антибактеріальними препаратами із широким спектром дії, використовуваними в лікуванні неускладнених форм запальних захворювань органів малого тазу, визнані макроліди. Серед них найкращу біодоступність, високу ефективність і можливість проведення пульс-терапії має азитроміцин. На українському фармацевтичному ринку представлено понад 20 препаратів азитроміцину. Єдиним генеричним препаратом азитроміцину в Україні зі встановленою біоеквівалентністю єхемоміцин.

Проведено порівняльне дослідження ефективності препарату хемоміцин (основна група) та інших генериків азитроміцину (група порівняння), зареєстрованих в Україні, в лікуванні 124 пацієнток із ендоцервіцитом і хронічним сальпінгоофоритом хламідійної етіології.

Результати дослідження показали, що під впливом лікування відзначалася практично повна редукція клінічної симптоматики в жінок основної групи. В групі порівняння позитивна динаміка була значно менш виражена. В основній групі ефективність лікування хламідійної інфекції за даними контрольного обстеження склала 100\%, а в групі порівняння у 16,1\% випадків відзначено неуспіх. Відновлення нормального вагінального біотопу було зареєстровано в 95,6\% спостережень в основній групі, а в групі порівняння у 23,2\% пацієнток зберігалася кокова флора.

Таким чином, використання хемоміцину перевершує за своєю ефективністю інші генерики азитроміцину при проведенні пульс-терапії. Призначення хемоміцину забезпечує повну елімінацію хламідійної інфекції, завершення запальної реакції тканин, відновлення лактобацилярного біотопу і захисних властивостей цервікального слизу. За своїми фармакоекономічними властивостями і клінічною ефективністю хемоміцин є препаратом вибору антибактеріальної терапії генітального хламідіозу.

Ключові слова: запальні захворювання органів малого тазу, хламідіоз, азитроміцин, хемоміцин.

\section{THE CHOICE OF MEDICATION FOR TREATMENT OF PATIENTS WITH CHRONIC PELVIC INFLAMMATORY DISEASES}

0.V. Grishchenko, MD, professor, Head of the Gynecology and Perinatology Department, Kharkiv Medical Academy of Postgraduate Education

I.V. Lakhno, PhD, assistant professor of the Gynecology and Perinatology Department, Kharkiv Medical Academy of Postgraduate Education

V. I. Ostanina, Kharkiv Municipal Clinical Maternity House with Neonatological Hospital

E.V. Miliutin, Kharkiv Municipal Clinical Maternity House with Neonatological Hospital

Patients with chronic pelvic inflammatory diseases are often exceeding $2 / 3$ among women seeking for the obstetrician-gynecologist help. To determine the therapeutic strategy it is need clear ideas about the most common cause of pelvic inflammatory diseases and methods of their treatment. In practice, the most frequently are chlamydia and mycoplasma infection, gonorrhea rate is gradually reduced. Among the antibacterial agents with a wide spectrum of activity macrolides are the most popular in the treatment of uncomplicated forms of pelvic inflammatory diseases. Among them azithromycin has the best bio-availability, high efficiency and the possibility for pulse therapy. On the Ukrainian pharmaceutical market represented more than 20 azithromycin drugs. Hemomycin is the only azithromycin generic drug in Ukraine with establishing bioequivalence.

The comparative study of hemomycin efficiency (main group) and other generic azithromycin medications registered in Ukraine (comparison group) in the treatment of 124 patients with chronic salpingoophoritis and cervicitis of chlamydial etiology was performed.

After treatment in women of the main group there was almost complete reduction of clinical symptoms. In the comparison group positive dynamics was significantly less pronounced. In the main group the efficiency of chlamydial infection treatment was $100 \%$, while in the comparison group $16.1 \%$ of cases marked failure. Restoration of normal vaginal biotope was reported in $95.6 \%$ of patients in the main group and in the comparison group in $23.2 \%$ of patients remained cocci flora.

Hemomycin is superior in their effectiveness comparatively to other generic azithromycin drugs with pulse therapy regimen application. The appointment of hemomycin provides complete elimination of chlamydial infection, the completion of the inflammatory tissue response, vaginal flora restoration and protective properties of cervical mucous. According to the pharmacoeconomic qualities and clinical efficiency hemomycin is the drug of choice for antibacterial therapy of genital chlamydiosis.

Keywords: pelvic inflammatory diseases, chlamydia, azithromycin, hemomycin. 